\title{
IMPROVED JENSEN'S INEQUALITY
}

\author{
MOHAMMAD SABABHEH
}

Abstract. In this article we present refinements of Jensen's inequality and its reversal for convex functions, by adding as many refining terms as we wish. Then as a standard application, we present several refinements and reverses of well known mean inequalities.

Mathematics subject classification (2010): 26A51, 26D15, 26B25, 39B62, 47A63, 47A64.

Keywords and phrases: Jensen's inequality, convex functions, means inequalities, Wiener index.

\section{REFERENCES}

[1] J. ALDAZ, Self-improvement of the inequality between arithmetic and geometric means, J. Math. Ineq. 3, 2 (2009), 213-216.

[2] J. ALDAZ, A refinement of the inequality between arithmetic and geometric means, J. Math. Ineq. 2, 4 (2008), 473-477.

[3] C. CondE, Young type inequalities for positive operators, Ann. Funct. Anal. 4, 2 (2013), 144-152.

[4] K. Das And I. Gutman, On Wiener and multiplicative Wiener indices of graphs, Discrete applied mathematics 206 (2016), 9-14.

[5] S. S. DRAGOMIR AND F. P. SCARMOZZINo, Refinement of Jensen's discrete inequality for differentiable convex functions, RGMIA research report collection, 5, 4 (2002).

[6] S. S. Dragomir, Some refinements of Jensen's inequality, J. Math. Anal. Appl. 168, 2 (1992), 518 522.

[7] S. S. Dragomir, A further improvement of Jensen's inequality, Tamkang J. Math. 25, 1 (1994), $29-36$.

[8] S. S. Dragomir, An improvement of Jensen's inequality, Bull. Math. Soc. Sci. Math. Roumanie 34, 82 (1990), 291-296.

[9] I. Gutman, W. Linert, I. Lukovits And Ž. TOMOvic, The multiplicative version of the Wiener index, J. Chem. Inf. Comput. Sci. 40 (2000), 113-116.

[10] I. Gutman, W. LinerT, I. Lukovits And Ž. TOMOVIC, On the multiplicative Wiener index and its possible chemical applications, Monatsh. Chem. 13 (2000), 421-427.

[11] F. Kittaneh, On the convexity of the Heinz mean, Integr. Equ. Oper. Theory 68 (2010), 519-527.

[12] F. Kittaneh And Y. Manasrah, Improved Young and Heinz inequalities for matrices, J. Math. Anal. Appl. 36 (2010), 262-269.

[13] M. KRniĆ, N. LOVRIČEviĆ, J. PeČARIĆ, Jensen's functional, its properties and applications, An. Stiint. Univ. "vidius" Constanta Ser. Mat. 20, 1 (2012), 225-247.

[14] M. Krnić, N. LovričEvić, J. PeČARIĆ, On the properties of McShane's functional and their applications, Period. Math. Hungar. 66, 2 (2013), 159-180.

[15] W. LIAO AND J. WU, Reverse arithmetic-harmonic mean and mixed mean operator inequalities, J. Inequal. Appl., 2015:215.

[16] W. Liao, J. Wu AND J. Zhao, New versions of reverse Young and Heinz mean inequalities with the Kantorovich constant, Taiwanese J. Math. 19, 2 (2015), 467-479.

[17] F. Mitroi, About the precision in Jensen-Steffensen inequality, Annals of the University of Craiova, 37, 4 (2010), 73-84.

[18] J. PeČARIĆ AND S. S. DRAGOMIR, A refinements of Jensen inequality and applications, Studia Univ. Babeş-Bolyai, Mathematica, 24, 1 (1989), 15-19.

[19] M. Sababheh AND M. SAl Moslehian, Advanced refinements of Young and Heinz inequalities, J. Number Theory, 172 (2017), 178-199. 
[20] M. SaBABHeH AND D. CHOI, A complete refinement of Young's inequality, J. Math. Anal. Appl. 440, 1 (2016), 379-393.

[21] M. SABABHEH, Log and Harmonically log-convex functions related to matrix norms, Oper. Matrices, 10, 2 (2016), 453-465.

[22] M. SABAвHEH, Integral Inequalities of the Heinz Means as Convex Functions, J. Math. Ineq. 10, 2 (2016), 313-325.

[23] J. ZHAO AND J. Wu, Operator inequalities involving improved Young and its reverse inequalities, J. Math. Anal. Appl. 421 (2015) 1779-1789.

[24] H. Zuo, G. SHI, M. FuJII, Refined Young inequality with Kantorovich constant, J. Math. Inequal. 5, 4 (2011), 551-556. 